\title{
A Complete Review Article on ABC of Blood Groups
}

\author{
Purna Singh A* ${ }^{1}$, Shivanand S Rathod ${ }^{1}$, Praveen K Kodumuru ${ }^{1}$, Desai JM1 and Vaishali Nagose ${ }^{2}$ \\ ${ }^{1}$ Department of Physiology, Mamata medical college (AP) \\ ${ }^{2}$ Department of Pathology. Mamata medical college (AP).
}

\section{Abstract}

$\mathrm{ABO}$ and Rh blood group systems are the most important blood grouping systems from clinical aspect. Determination of blood group is important for blood transfusion therapy, medico-legal purposes, organ transplantation, settlement of paternity disputes etc. Nearly 25 types of blood groups are present. $\mathrm{ABO}$ incompatibility between mother and fetus may produce infertility or hemolytic disease of the new born, and persons of certain blood groups have an increased susceptibility to peptic ulcer or gastric cancer. The purpose of this review is to summarize the concepts and origin of $\mathrm{ABO}$ and other blood groups systems and Chemistry of Blood group specificity (Glycoproteins found in body fluids).

Key Words:Blood groups and ABO typing.

\section{INTRODUCTION}

$\mathrm{T}$ he ABO Blood group system is discovered by the Austrian scientist Karl Landsteiner, who found three different blood types in 1900 . He was awarded Nobel Prize in 1930. Alfred Von Decastello and Adriano Sturli discovered the fourth type 'AB' in 1902[1].

\section{Types Of Blood Group Systems:}

The ABO system:

The epitopes of ABO antigens are determined by carbohydrates (sugars), which are linked either to polypeptides (forming glycoproteins) or to lipids (glycolipids). Antigenic differences between different species were recognized before differences within a species. Landois discovered that when the red blood cells of an animal, e.g. a lamb, when mixed with the serum of another animal (a dog) and incubated at 370C they will be lysed within $2 \mathrm{~min}$ [2].Landsteiner was prompted by the work of Landois to see whether it was possible to demonstrate differences, although presumably slighter ones, between individuals of the same species. As he later explained, he chose the simplest plan of investigation and simply allowed serum and red cells from different human individuals to interact [3]. $\mathrm{He}$ discovered that the red cells agglutinate if blood is incompatible and lead to discovery of ABO blood group system.

\section{MNS systems:}

After the discovery of the ABO Blood group system no new blood group systems were found for 25 years. Landsteiner and Witt examined human sera for antibodies other than anti-A and anti-B but could find only weak agglutinins active at low temperatures [4]. It occurred to Landsteiner and Levine that they might be able to reveal other antigens by injecting different samples of human red cells into rabbits. Antibodies identifying three new human antigens were obtained [5]; to the first of these the letter $\mathrm{M}$ was given to indicate that the antigen had been identified with immune serum ('I' was avoided because of confusion with the numeral 1[6].

The Rh system:

\author{
Address for correspondence* \\ Dr. Purna Singh A \\ Department of Physiology, Mamata medical college, Rotary \\ nagar, Khammam - 507002 (AP) India. \\ Purnasingha@gmail.com \\ ,+91-9849347366.
}

Antibodies demonstrating Rh polymorphism in humans were found in two different ways. Landsteiner and Wiener injected the red cells of rhesus monkeys into rabbits and guinea pigs and tested the resulting serum against human red cells [7]. Meanwhile, Levine and Stetson in 1939 found an antibody (which subsequently proved to be anti-Rh) in the serum of a recently delivered woman whose fetus had died in utero [8].

Bombay blood group:

Individuals belonging to Bombay blood group (oh) [9] are homozygous for the absence of $\mathrm{H}$ gene i.e., they are of the genotype ' $h$ h', so that they are unable to bring about the initial part of conversion of the precursor blood group substance [10]. This means that even if ' $\mathrm{A}$ ' and ' $\mathrm{B}$ ' genes are present they have no substrate for their normal function of producing ' $\mathrm{A}$ ' and 'B' blood group substances [10]. The ABO genes cannot therefore be expressed and such individuals appear to belong to ' $O$ ' but their true state can be detected because of the presence in their serum of anti-H .Thus the 'Bombay phenotype', lack 'A', 'B' and ' $\mathrm{H}$ ' antigens on their erythrocytes and in secretions. Nevertheless they appear to have normal 'A' and 'B' genes that can be expressed in the next generation if their children acquire an ' $\mathrm{H}$ ' gene from the other parent [11]. It follows that there is no 'O' antigen; group 'O' erythrocytes and the saliva of group ' $\mathrm{O}$ ' secretors contain ' $\mathrm{H}$ ' antigen, but the designation group ' $\mathrm{O}$ ' erythrocytes has been retained for historical reasons [12].

Lewis Blood Group System:

The Work of Mourant (1946) and subsequent work of Grubb (1951) and Ceppellini (1955) [13] showed that Lewis antigen is also found on red blood cells and is related to ABO system and secretion of $\mathrm{ABH}$ antigens. There are two types of Lewis antigen and designated as Lea and Leb respectively, and give rise to three red blood cell phenotypes which are designated as $\operatorname{Le}(\mathrm{a}-\mathrm{b}+), \operatorname{Le}(\mathrm{a}+\mathrm{b}-), \operatorname{Le}(\mathrm{a}-\mathrm{b}-)$. The synthesis of Le antigen is regulated by the independent gene Le. The Lewis antigen appears on the same glycoproteins as the ABH determinants [13]. These antigens are synthesized from the same precursor substance as ABH antigen [14].

Other blood group systems:

The structure and functions of the membrane proteins and glycoprotein carrying blood group antigens have been reviewed by carton [15] and Daniels[16]. The $\mathrm{H}$ antigen content of red cells depends on the ABO group and when assessed by agglutination reactions with anti- $\mathrm{H}$, the strength of reaction tends to be graded $\mathrm{O}$ 
$>\mathrm{A} 2>\mathrm{A} 2 \mathrm{~B}>\mathrm{B}>\mathrm{A} 1>\mathrm{A} 1 \mathrm{~B}$. Other subgroups are occasionally found. The A, B, and $\mathrm{H}$ antigens are detectable early in fetal life but are not fully developed on the red cells at birth. The number of antigen sites reaches adult level at around 1 year of age and remains constant until old age, when a slight reduction may occur. The ability to secrete A, B and $\mathrm{H}$ substances in water soluble form is controlled by FUT2 (dominant allele Se).

Between 1946 and 1971 the Kell (K), Duffy (Fy), Kidd (Jk), Diego (Di), Cartwright (Yt), Xg, Sc, Dombrock (Do) and Colton (Co), Lewis and Lutheran blood group systems were discovered. As shown in table 1.0, twenty-five blood group systems have been given numbers so far [17]. In numerical order, systems 001-025 are: ABO, MNSs, P1, Rh, Lu, Kell, Lewis, Fy, Jk, Di, Yt, Xg, Sc, Do, Co, LW, Chido/Rodgers, Hh, Kx, Ge(Gerbich), Cromer,knops,Indian,Ok.MER2 .

Table 1.0: Blood group systems recognized by the ISBT working party

\begin{tabular}{|c|c|c|c|c|}
\hline $\begin{array}{l}\text { System } \\
\text { number }\end{array}$ & $\begin{array}{l}\text { System } \\
\text { name } \\
\text { conventional }\end{array}$ & $\begin{array}{l}\text { System } \\
\text { symbol } \\
\text { ISBT }\end{array}$ & $\begin{array}{l}\text { Chromosomal } \\
\text { location }\end{array}$ & Gene (s) \\
\hline 1 & $\mathrm{ABO}$ & $\mathrm{ABO}$ & $9 q 34.1-q 34.2$ & $\mathrm{ABO}$ \\
\hline 2 & MNS & MNS & $4 q 28-q 31$ & $\begin{array}{l}\text { GYPA, } \\
\text { GYPB }\end{array}$ \\
\hline 3 & $\mathrm{P}$ & PI & 22q11.2-qter & $P$ \\
\hline 4 & $\mathrm{Rh}$ & RH & 1p36.2-p34 & RHD, RHCE \\
\hline 5 & Lutheran & $\mathrm{LU}$ & $19 q 12-q 13$ & LU \\
\hline 6 & Kell & KEL & $7 \mathrm{q} 33$ & KEL \\
\hline 7 & Lewis & LE & $19 \mathrm{p} 13.3$ & FUT3 \\
\hline 8 & Duffy & FY & $1 q 22-q 23$ & FY \\
\hline 9 & Kidd & JK & $18 \mathrm{q} 11-\mathrm{q} 12$ & HUT11 \\
\hline 10 & Diego & DI & $17 q 12-q 21$ & SLC4A1 \\
\hline 11 & $\mathrm{Yt}$ & YT & $7 q 22$ & ACHE \\
\hline 12 & $\mathrm{Xg}$ & $\mathrm{XG}$ & $\mathrm{Xp} 22.32$ & $\mathrm{XG}$ \\
\hline 13 & Scianna & $\mathrm{SC}$ & $1 \mathrm{p} 36.2-\mathrm{p} 22.1$ & $\mathrm{SC}$ \\
\hline 14 & Dombrock & DO & 12p13.2-p12.1 & DO \\
\hline 15 & Colton & $\mathrm{CO}$ & $7 \mathrm{p} 14$ & AQP1 \\
\hline 16 & LW & LW & 19p13.2-cen & LW \\
\hline 17 & chido/Rogers & $\mathrm{CH} / \mathrm{RG}$ & $6 \mathrm{p} 21.3$ & $\mathrm{C} 4 \mathrm{~A}, \mathrm{C} 4 \mathrm{~B}$ \\
\hline 18 & $\mathrm{H}$ & $\mathrm{H}$ & $19 q 13$ & FUT1 \\
\hline 19 & $\mathrm{Kx}$ & $\mathrm{XK}$ & $\mathrm{Xp} 21.1$ & $\mathrm{XK}$ \\
\hline 20 & Gerbich & GE & $2 q 14-q 21$ & GYPC \\
\hline 21 & Cromer & CROM & $1 \mathrm{q} 32$ & $\mathrm{DAF}$ \\
\hline 22 & Knops & $\mathrm{KN}$ & $1 \mathrm{q} 32$ & CR1 \\
\hline 23 & Indian & IN & $11 \mathrm{p} 13$ & CD44 \\
\hline 24 & Ok & $\mathrm{OK}$ & 19pter-p13.2 & OK \\
\hline 25 & MER2 & RAPH & $11 \mathrm{p} 15$ & MER2 \\
\hline
\end{tabular}

\section{REVIEW OF LITERATURE}

Epstein and Ottenberg in 1908 suggested that ABO blood groups were inherited, and this was confirmed by Von Dungern and Hirsfeld in 1910. The exact manner was published by Bernstein in 1924[13].

Attempts were made earlier to 1900 , to replace blood, for example, in cases of hemorrhage, by transfusion of a donor's blood. In some instances, the therapy met with success and in some severe as well as fatal hemolytic reaction occurred. In other words, blood of some people was compatible and that of others incompatible. One could not understand the cause of this phenomenon at that time and they attributed it to some unknown immunological differences between the recipient and the donor.

In 1875, Landois noticed that if red blood cells of an animal of one species were mixed with serum from an animal of another species, clumping or agglutination of red blood cells usually occurred [13]. The phenomenon was recognized as being similar to that which followed the mixing of bacteria with appropriate immune sera.

Landsteiner from his observations stated "if an agglutinogen is present on the red blood cells of a blood, the corresponding agglutinin is absent from the plasma; if the agglutinogen is absent the corresponding agglutinin must be present" [18]. This statement is popularly known as Land Steiner's law. The Landsteiner law, however, is not always true, for example, 'Rh' negative persons need not and normally do not contain anti-Rh agglutinin but may develop the agglutinin as a result of immunological response (Sensitization). When 'Rh' positive red blood cells enter the subject's circulation during blood transfusion or maternal circulation from the 'Rh' positive fetus

Landsteiner (1901) and later workers, namely, Jansky (1907) and moss (1907) showed that the red blood cells of all the individuals can be grouped according to the presence of two blood group substances or agglutinogens called 'A' and 'B', into four main blood groups 'A', 'B', 'AB' and 'O' [19]. Table 2.0 shows blood group phenotype, antigen present on red blood cells and agglutinins present in Plasma (serum):

Group ' $\mathrm{A}$ ' is further subdivided into 'A1' and 'A2'. Anti-A serum contains two antibodies anti-A and anti-A1; it is generally believed that 'A1' has two antigens, 'A' and 'A1', while 'A2' has only one 'A'. 'A2' cells react weakly with anti-A serum; hence a high titre serum is necessary while grouping; 'A2B' cell react even less readily with anti-A serum. The subgroups of $A$ increase the number of groups from four to six; 'A1','A2' ,'B', 'A1B' , 'A2B' and 'O.'

The main four groups of $\mathrm{ABO}$ system are inherited as Mendelian characters by three allelic genes, A, B, and $\mathrm{O}$

Table 2.0 ABO Blood group system in different individuals

\begin{tabular}{|c|c|c|}
\hline $\begin{array}{c}\text { Blood group } \\
\text { phenotype }\end{array}$ & $\begin{array}{c}\text { Antigen on } \\
\text { RBC }\end{array}$ & $\begin{array}{c}\text { Antibodies in } \\
\text { serum }\end{array}$ \\
\hline AB & A and B & $-($ nil) \\
\hline A & A & Anti-B $(\beta)$ \\
\hline B & B & Anti-A $(\alpha)$ \\
\hline O & None & Anti-AB $(\alpha \beta)$ \\
\hline
\end{tabular}


Chemistry of Blood group specificity (Glycoproteins found in body fluids):-

Blood

Group

Action of

Genes

Precursor

substance

synthesis by

unidentified

gene.

L-fucose is

added to

precursor by

'H' gene.

$\mathbf{A}$

$\mathrm{N}$-acetyl-D-

galactosamine is added to $\mathrm{H}$ active chain by 'A' gene,

D-galactose is added to $\mathrm{H}-$ active chains by 'B' gene, 


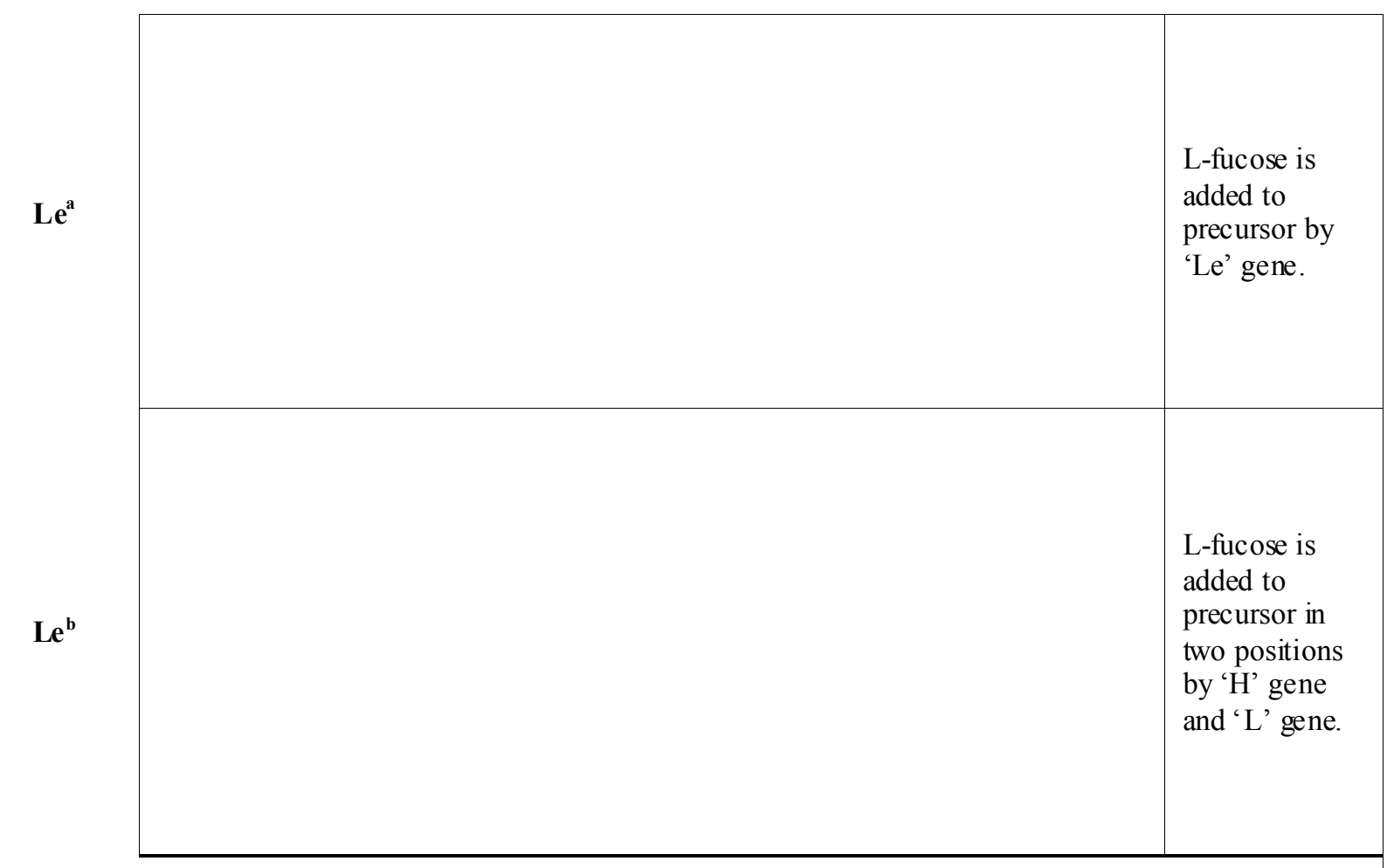

Table 3.0: Proposed structure of carbohydrate side chian of $A, B, H, L e^{a}$ and $L^{b}$ glycoproteins

(Thompson, R.B. et al.,). The dominant 'A' and 'B' determine the presence or absence of the corresponding blood group substance so that an individual who inherits an A gene from each parent will be of genotype 'AA', and similarly with 'B'. The inheritance of 'A' from one parent and ' $\mathrm{B}$ ' from the other will result in the genotype 'AB'. The ' $\mathrm{O}$ ' gene may be paired with either 'A' or 'B' but has no suppressive effect so that an individual of genotype 'AO' or 'BO' reacts as group 'A' or 'B' respectively. When ' $\mathrm{O}$ ' gene inherited from each parent the genotype is 'OO' and the $\mathrm{g}$

$$
\text { Genotype }
$$

Group

Phenotype

$$
\mathrm{AB}
$$

$$
\mathrm{AA} \text { or AO }
$$$$
\mathrm{BB} \text { or } \mathrm{BO}
$$

The genotype of an individual, say 'AA' or 'AO' cannot be determined serologically for he will react as group ' $\mathrm{A}$ ' in either case. The true genotype may however, be determined by appropriate family studies [10]. Table 3.0 shows the Proposed structure of carbohydrate side chian of A, B, H, Lea and Leb glycoproteins.

\section{Importance Of Blood Groups:-}

Only $\mathrm{ABO}$ and $\mathrm{Rh}$ Blood group systems are having major clinical importance from the point of view of blood transfusion and others are of less importance because the corresponding antibodies are either absent normally or occur rarely, and when present, they usually react at low temperature (cold agglutinins) (Dacie and Lewis et al.,) and do not precipitate transfusion.

Blood groups study forms a comparatively small field of study but they have important Place in genetics, immunology, anthropology, Clinical medicine and in forensic medicine. , blood groups can be applied to various problems of identity, parentage and paternity. In addition the $\mathrm{ABO}$ and Lewis antigens of secretors can be used in the examination of dried stains of saliva, seminal stains and plasma. The blood group systems in addition to blood replacement therapy are now being applied to study genetic inheritance, serological and immunological problems, anthropological studies and legal medicine.

In case of hemorrhagic shock whole blood transfusion is given and anemia's packed cell volume transfusion is given. They play important role in rejection of organ transplant along with histo compatability factors. It is also used in medico legal disputes of Individuals who are accused of being father of a given child. It is also used to trace culprits in case of murders, rapes as $\mathrm{ABH}$ Substances are absorbed on RBC 'S from the substances that are present in seminal fluid. Secretion of these Blood group substances in saliva in some way or other is concerned with inheritance of diseases, liability o develop particular disease and may be major cause of infertility.

\section{CONCLUSION}

Finally Blood group substances play a major role in saving individual from hemorrhagic shock (Hypovolemic shock); treating anemia's refractory to medicines. They help identify of individuals in medico legal cases. They may be a major cause of infertility and rejection of organ transplant.

\section{REFERENCES}


1. Speiser P, Smekal FG. Karl Landsteiner. 2nd ed. Wien: Brüder Hollinek; 1975.

2. Landsteiner $\mathrm{K}$. Individual differences in human blood. Science 1931; 73:405.

3. Landois L. Die Transfusion des Blutes 1875, F.C.W. Vogel, Leipzig.

4. Landsteiner K, Witt D.H. Observations on the human blood groups. Irregular reactions. Iso-agglutinin in sera of group 4. The factor A1. J Immunology 1926; 11:221.

5. Landsteiner K, Levine P. Further observations on individual differences of human blood. Proc Soc exp Biol 1927; 24:941.

6. Levine P. Landsteiner's concept of the individuality of human blood. Exp Med Surg 1944;11:36.

7. Landsteiner K, Wiener A.S. Studies on an agglutiongen (Rh) inhuman blood reacting with anti-Rhesus sera and with human iso-antibodies. J exp Med 1941; 74:309.

8. Levine $\mathrm{P}$, Stetson R. An unusual case of intra-group agglutination. J Amer med Assoc 1939; 113:126.

9. Bhende YM, Deshpande CK, Bhatia HM, Sanger R, Race RR, Morgan WT, Watkins WM.Indian J Med Res. 1994 Feb;99:3.

10. Thompson RB. Disorders of blood. Edinburgh, London and
New York, Churchill Livingstone 1977:291-292.

11. Donald M, Marcus. The ABO and Lewis blood group system; immunochemistry, genetics and relation to human disease. New Eng J Med 1969; 280:994-1006.

12. Maxwell M, Wintrobe. Clinical Hematology Seventh edition, Philadelphia, Lea \& Fibiger. 1972:451-472.

13. Race R.R, Sanger, Ruth. Blood Groups in Man, 4th edn. 1962, Blackwell Scientific Publications, Oxford.

14. Maxwell M, Wintrobe. Clinical Hematology Seventh edition, Philadelphia, Lea \& Fibiger. 1972:451-472.

15. Cartron, J.P.and Agre, P. (1993).Blood group antigens: Protein and gene structure. Seminars in Hematology, 30,193.

16. Daniels, G.L., and 25 others (1993).ISBT Working party on terminology for red cell surface antigens: Sao Paulo Report .Vox Sanguinis, 65, 77.

17. Mollison PL. Blood transfusion in clinical medicine Sixth edition, Oxford, E.L.B.S. and Blackwell Scientific Publications 1979; Page-244-248; 285-290;425-426.

18. Samson Wright Applied Physiology, Thirteenth edition, Medical Oxford Publications.

19. Otakar Jaroslav Pollak. Grouping Typing and Banking of Blood First edition, Springer field (U.S.A.), Charles C Thomas 1951.Page 3, 22 and 30. 